\title{
ВИКОРИСТАННЯ МІНЕРАЛЬНОЇ ВОДИ ПРИ ЗАХВОРЮВАННЯХ ШЛУНКОВО-КИШКОВОГО ТРАКТУ
}

\author{
О. В. Бугрименко
}

Лебединське медичне училище, Сумська область

У статті проаналізовано значення і можливості застосування мінеральної води при захворюваннях шлунково-кишкового тракту.

\section{USAGE OF MINERAL WATER FOR TREATMENT OF THE DISEASES OF GASTROINTESTINAL TRACT}

\author{
O. V. Buhrymenko
}

\section{Lebedynsk Medical College, Sumy Region}

The article is devoted to the importance and opportunities for usage of mineral water for treatment of the diseases of gastrointestinal tract.

Вступ. Водолікування відоме з найдавніших часів. Перші відомості містяться в індуїстських Ведах (1500 років до н. е.). Прісну і мінеральну воду використовували для гігієнічних і лікувальних цілей древні ассирійці, вавілонці, єгиптяни. У Древній Греції техніку водолікування удосконалив Гіппократ, а пізніше їі запозичили в Древньому Римі і поступово поширилося по усьому світі. Принцип водолікування ґрунтується на тому, що вода, володіючи високою теплоємністю, великою теплопровідністю і конвекцією, добре розчиняючи різні солі та гази, при впливі на організм через нервові рецептори шкіри та слизову ШКТ викликає позитивні хімічні й біохімічні зміни в організмі.

Кожна мінеральна вода складається зі звичайної води, газів і розчинених у ній твердих мінеральних і органічних речовин.

Вода - не простий розчинник, а особливе середовище, без якого не можуть перебігати життєві процеси організму. Голодуючий може втратити весь жир, глікоген і половину білків і все-таки продовжувати жити, а втрата 10 \% води призводить до загибелі організму. В організмі людини найбільшою за масою складовою частиною $\epsilon$ вода.

(C) О. В. Бугрименко, 2014
Кількість ї̈ в тілі зародка на початку утробного періоду близько $90 \%$ загальної маси, у немовлят знижується до 70-75 \% і поступово до $60 \%$ - у дорослих. Вода міститься в клітинах тіла й у міжклітинних проміжках.

Основна частина. В результаті вживання мінеральної води відбувається сумарна дія солей, що містяться в ній, та інших речовин, які проникають через слизову оболонку в кров. Хімічний склад клітин різний. У їх ядрі $\epsilon$ фосорор, в еритроцитах залізо, калій і фросфор, у міжклітинній рідині натрій і хлор [1]. Білок щитоподібної залози характеризується своїм з'єднанням з йодом. Усі ці речовини, надходячи в організм із мінеральною водою, можуть диференціювати, проникати у відповідні тканини. Необхідно поповнювати запас даних речовин у тих клітинах, тканинах і органах, які їх найбільше потребують і в яких мають місце порушення обміну саме цих речовин.

Бальнеотерапія (від лат. balneum - купання і терапія) - це лікування мінеральними водами, приймання внутрішньо та зовнішні процедури (душі ванни, примочки тощо) [3]. Іноді в структурі бальнеотерапії помилково розглядають грязелікування, морські ванни, купання в лиманах, у ропі солоних озер (ропні ванни). 
Мінеральні води діють на організм температурою, хімічним складом, гідростатичним тиском. Крім того, нервові рецептори піддаються роздратуванню газами $\left(\mathrm{CO}_{2}, \mathrm{H}_{2} \mathrm{~S}, \mathrm{NO}_{2}\right.$ і радіоактивними речовинами (радон), що проникають через шкіру, слизові оболонки і дихальні шляхи в кров. Мінеральні води при бальнеотерапії застосовують при різних захворюваннях.

Протипоказання: порушення кровообігу вище I-I ступеня, інфекційні захворювання в гострій стадіi, злоякісні пухлини, туберкульоз в активній фразі, цироз печінки, хронічні захворювання нирок, системні хвороби крові в гострій стадіi, різке загальне виснаження [2]. Застосування мінеральних вод протипоказано при звуженні стравоходу і воротаря шлунка, різкому опущенні шлунка, серцево-судинних захворюваннях, що супроводжуються набряками, порушеннями видільної здатності нирок.

Характеристика і класифікація мінеральних вод проводиться за їх хімічним складом і фрізичними властивостями. При цьму враховується загальна мінералізація, іонний і газовий склад, радіоактивність, температура, реакція середовища. За кількістю компонентів у грамах на один літр розрізняють мінеральні води: слабкої мінералізації (1-2 г/л), малої мінералізації (2-5 г/л), середньої (5-15 г/л) і високої мінералізації (15-30 г/л).

Ступінь мінералізації води визначає можливості iï лікувального застосування [4]. Зміст мінеральних речовин більше 10-12 г/л у хлоридних водах $€$ максимальним для використання їх у натуральному вигляді при внутрішньому вживанні. Води високої мінералізації застосовують для ванн. Ефективність лікування слабомінералізованими водами зумовлена не ї іонним складом, а змістом органічних біологічно активних речовин, кремнієвої кислоти, радіоактивністю, підвищеною температурою. Іонний склад мінеральних вод може бути найрізноманітнішим, але основне значення мають іони хлору, натрію, кальцію, магнію. Газовий склад вод залежить від кількості вільного чи розчиненого газу, однак для лікувального застосування важлива наявність вуглекислого газу, сірководню, азоту, метану [5]. Мінеральні води використовують на курортах для пиття, ванн, купань у лікувальних басейнах, усіляких душів, а також для інгаляцій і полоскань при захворюваннях горла і верхніх дихальних шляхів, для зрошення при гінекологічних захворюваннях. Мінеральні води приймають внутрішньо і поза межами курорту, коли користуються привізними водами, розлитими в пляшки. Налита в пляшки вода насичується двоокисом вуглецю для збереження їі хімічних властивостей і смакових якостей; вона повинна бути безбарвною, абсолютно чистою; пляшки 3 мінеральною водою зберігають у горизонтальному положенні в прохолодному місці. Лікування пляшковими мінеральними водами повинно поєднуватися з дотриманням визначеного режиму, дієти і використанням додаткових лікувальних фракторів (фрізіотерапіі, медикаментозного лікування, гормональної терапії і под.). Мінеральні води, переважно невисокої мінералізації й утримуючі іони кальцію, володіють вираженою діуретичною (сечогінною) дією і сприяють виведенню з нирок та сечового міхура бактерій, слизу, піску, і навіть дрібних конкрементів [6]. Лікування мінеральними водами повинно проводитися за призначенням лікаря і під лікарським контролем. Деякі мінеральні води застосовують як освіжаючий, добре тонізуючий столовий напій, що сприяє підвищенню апетиту, і вживають замість прісної води, без яких-небудь медичних показань. У ряді районів нашої країни звичайна питна вода досить сильно мінералізована і цілком обґрунтоване вживання їі як столового напою. Можна використовувати столові мінеральні води хлоридно-натрієвого типу з мінералізацією не вище 4-4,5 г /л (для гідрокарбонатних вод - близько 6 г/л). Столові води малої мінералізації (менше грама на літр) $\epsilon$ екологічно чистим продуктом. Їхнє безсумнівне достоїнство - можливість застосування як для приготування їжі, так і для вживання чистого прохолодного напою. Це особливо актуально в наші дні: сучасні мегаполіси характеризуються значним забрудненням навколишнього середовища і підвищеною концентрацією шкідливих речовин у водопровідній воді навіть після ї̈ очищення. У цих умовах столові мінеральні води є єдиною можливою альтернативою. Дія мінеральних питних вод на організм зумовлена хімічним, механічним і термічним фракторами. Провідним є хімічний фрактор, зумовлений іонним складом прийнятих вод. Іони, що містяться в мінеральній воді, потрапляючи в травний тракт, стимулюють виділення слини, а потім і секрецію шлунка. Іони входять до складу шлункового соку, тому відбувається посилення (чи ослаблення) його секреції зміна складу. Далі в кишечнику відбувається всмоктування іонів мінеральної води в кров і регулюється діяльність кишечнику, печінки і нирок. Гідрокарбонатні іони 
стимулюють шлункову секрецію, а при переході в дванадцятипалу кишку гальмують ї. При нормальній чи зниженій секреції частина гідрокарбонатних іонів активує процеси утворення соляної кислоти в шлунку, а вуглекислий газ сприяє розрідженню і видаленню слизу зі шлунка і нейтралізації шлункового вмісту. Зниження кислотності вмісту кишечнику гальмує утворення сечової кислоти і прискорює їі виділення, перешкоджаючи утворенню каменів у нирках. Такі води розріджують мокротиння, зменшують її в'язкість і підвищують виділення з трахеї і бронхів [7]. Сульфратні іони, подразнюючи рецептори шлунка, помітно знижують шлункову секрецію, прискорюють евакуацію̈̈жі зі шлунка в кишечник. Надходячи з їжею в кишечник, вони підвищують його рухову функцію. Крім того, сульфати викликають скорочення жовчного міхура, прискорюють утворення і виведення жовчі з печінки в дванадцятипалу кишку. У поєднанні з іонами кальцію сульфати сприяють виведенню шкідливих речовин з організму. Іони кальцію стимулюють ріст кісток і зубів, у яких знаходиться до $99 \%$ усього кальцію в організмі. При прийманні кальцієвих вод внутрішньо відновлюється збудливість головного мозку і скелетних м' язів та моторна діяльність кишечнику, підсилюється скорочувальна функція серця, підвищується згортання крові. Іони магнію стимулюють утворення речовин, що регулюють транспорт іонів у тканинах. При прийманні магнієвих мінеральних вод відновлюється дефріцит іонів магнію, що розвивається при захворюваннях і супроводжується зниженою секрецією шлунка, обміном цукрів і білків. Приймання залізистої води відновлює дефіцит заліза, що розвивається при анеміях різного походження, а також стимулює утворення гемоглобіну. Залізо (разом з марганцем і міддю) також входить до складу ферментів, що відіграють ключову роль в окисненні жирів і цукрів. Гідрокарбонатно-сульфатні лікувально-столові мінеральні води з незначним вмістом чи відсутністю вуглекислого газу і розчинених органічних речовин показані хворим із хронічними гастритами 3 підвищеною секреторною функцією, неускладненою виразковою хворобою, хронічними захворюваннями верхніх дихальних шляхів. Їх приймають підігрітими до $38-45^{\circ} \mathrm{C}$ три рази на день за 60-90 хв до приймання їжі або через годину після неї. Мінеральну воду починають пити з половини склянки, доводячи до кінця курсу лікування разову дозу до півтори склянки. Гідрокарбонатно-хло- ридно-сульфратні лікувально-столові та лікувальні мінеральні води призначають звичайно хворим із хронічним гастритом зі зниженою секрецією шлунка. Мінеральні води підігріті до 18-26 ${ }^{\circ} \mathrm{C}$ приймають три рази на день за 15-30 хв до ̈ди. Їх п'ють у тих же дозах, що і попередні. Гідрокарбонатно-сульфатні кальцієві лікувально-столові води вживають також і при хронічних захворюваннях кишечнику з підвищеною моторикою. Підігріту до 40-45 ${ }^{\circ} \mathrm{C}$ мінеральну воду п'ють три рази на день за 30-50 хв до приймання їжі по половині склянки або склянці. 3 появою болю і проносу питне лікування тимчасово припиняють.

Хлоридно-сульфатні лікувальні мінеральні води показані людям із хронічними захворюваннями кишечнику, що супроводжуються зниженою руховою функцією (запорами), а також із захворюваннямижовчовивідних шляхів, цукровим діабетом, ожирінням та подагрою. Воду 18-24 ${ }^{\circ} \mathrm{C}$ приймають по одній склянці три рази на день за 30-50 хв до ̈̈и і на ніч. Гідрокарбонатно-хлоридно-сульфатні лікувально-столові води вживають також при хронічних захворюваннях печінки і підшлункової залози. Їх приймають підігрітими до $42-45^{\circ} \mathrm{C}$ три рази на день за 60-90 хв до їди. За одне приймання випивають одну-дві склянки води.

Найкращий спосіб приймання мінеральної води внутрішньо - безпосередньо з джерела. Не рекомендується приносити воду наперед на добу. Основною умовою ефективності питного лікування є встановлення величини разової дози, числа приймань на день, тривалість курсу лікування. Дозування мінеральної води виробляється з урахуванням фрізичного стану хворого, його віку, характеру і стадії захворювання.

Загальновизнаним є метод розрахунку дози за масою тіла хворого: 3-5 мл води на 1 кг маси при захворюваннях шлунково-кишкового тракту і до 10 мл при захворюваннях сечостатевої системи. Істотне значення має час приймання води. Найбільша активність секреторної і фрерментативної діяльності шлунка спостерігається через 15-20 хв після приймання води, тому мінеральну воду призначають у визначений термін залежно від приймання їжі з урахуванням кислотності шлункового соку. При зниженій кислотності мінеральну воду приймають за 30-45 хв до їди, при підвищеній - за 45-60 хв.

Основні показання до приймання мінеральної води:

1) хронічні гастрити; 
2) виразкова хвороба шлунка і дванадцятипалої кишки з підвищеною, зниженою і нормальною секрецією поза фазою загострення чи у фазі згасаючого загострення при відсутності порушення моторно-евакуаторної функції шлунка і схильності до кровотечі;

3) захворювання товстого і тонкого кишечнику поза загостренням;

4) дискінезії кишечнику;

5) хронічні гепатити, холецистити в стадії ремісії згасаючого загострення без явища жовтяниці;

6) стан після хвороби Боткіна - не раніше 4-5 місяців;

7) жовчнокам'яна хвороба;

8) хронічні панкреатити;

9) ожиріння;

10) захворювання сечовивідних шляхів - пієлонефрити, хронічні цистити, сечокам' яна хвороба.

Висновки. Вода сама по собі необхідна для життєдіяльності організму. Але є вода з особливими цілющими властивостями. На місці джерел цілющої води зараз розміщені світові курорти. Увесь цей час властивості мінеральних вод із різних джерел вивчали і застосовували на практиці при багатьох хворобах. Сучасна медицина дає повний опис мінеральних вод і показання для їх застосу-

\section{ЛІТЕРАТУРА}

1. Боголюбов В. М. Фізичні фактори у профрілактиці, лікуванні та медичній реабілітації / В. М. Боголюбов. М. : Медицина, 2000.

2. Боголюбов В. М. Загальна фрізіотерапія : підручник /

В. М. Боголюбов, Г.Н.Пономаренко. - М., 1999.

3. Клінічна фрізіотерапія / за ред. В. В. Оржешковського. - Київ, 1999.

4. Клячкин Л. М. Фізіотерапія / Л. М. Клячкин, М. М. Виноградова. - М., 1995. вання. 3 лікувальними цілями (як зовнішньо, так і внутрішньо) застосовують найрізноманітніші мінеральні води. Їх властивості, класифікація, критерії оцінки терапевтичного впливу на організм при різних захворюваннях вивчає і розробляє бальнеологія. До лікувального відносять тільки ті мінеральні води, вміст хімічних компонентів і фрізичні властивості яких відповідають прийнятим нормам, розробленим на основі багаторічного досвіду лікувального застосування і спеціальних досліджень. В результаті вживання мінеральної води відбувається сумарна дія солей, що містяться в ній, та інших речовин, які проникають через слизову оболонку в кров. Варто пам'ятати, що мінеральні питні води показані далеко не всім. Вони протипоказані при загостреннях хронічних захворювань шлунково-кишкового тракту з блюванням, проносом, кровотечею і різким болючим синдромом, при жовчнокам'яній хворобі, гострому холециститі, звуженні стравоходу і воротаря, недостатності кровообігу і гострій затримці сечі. Ефективність внутрішнього застосування мінеральних вод тим вища, чим правильніше підібраний клас мінеральних вод і суворе дотримування пацієнтами запропонованої лікарем методики лікування.

5. Пономаренко Г. М. Фізичні методи лікування : довідник / Г. М. Пономаренко. - СПб., 2002.

6. Улащик В. С. Загальна фрізіотерапія : підручник / В. С. Улащик, І.В.Лукомський. - Мінськ : «Книжковий дім», 2003.

7. Фізіотерапія / за ред. М. Вейса і А. Зембатого ; пер. з польської. - М. : Медицина, 2004.

Отримано 11.03.14 